\title{
PENGARUH KEPEMIMPINAN, DIKLAT DAN BUDAYA ORGANISASI TERHADAP KINERJA PEGAWAI DIREKTORAT JENDERAL PEMBINAAN PENEMPATAN TENAGA KERJA KEMENAKETRANS RI
}

\author{
Olos Wasahua \\ Program Studi Pendidikan Ekonomi, FIPPS \\ Universitas Indraprasta PGRI \\ E-mail : olosnailamwasahua@gmail.com
}

\begin{abstract}
This study to determine the effect simultaneously and partially between Leadership, Training and Organizational Culture on Employee Performance At Directorate General of Manpower Placement Development Kemenaketrans RI. This research method is quantitative research method. The population in this study is 394 employees and the sample used is 80 samples with 10\% erorsampling .. The test used is: test of validity and reliability, correlation test, simple linear regression, $t$ test and $F$ test where the significance of trust 95\% $(\alpha=0.05)$. All statistical tests were performed using SPSS (Statistical Package for Social Science) version 19. The results showed that leadership, training and organizational culture together have a positive influence on employee performance shown by coefficient of determination $R 2=0.107$ and multiple regression equation $=28.383+0.010 X 1+$ $0.276 X 2-0.002 X 3$ so that the contribution and influence of leadership, training and organizational culture together on employee performance is significant.
\end{abstract}

Keyword: leadership, training, organizational culture, employee performance

\begin{abstract}
ABSTRAK
Penelitian ini untuk mengetahui pengaruh secara simultan dan parsial antara Kepemimpinan, Diklat dan Budaya Organisasi Terhadap Kinerja Pegawai Pada Direktorat Jenderal Pembinaan Penempatan Tenaga Kerja Kemenaketrans RI. Metode penelitian ini adalah metode penelitian kuantitatif. Populasi dalam penelitian ini adalah Pegawai berjumlah 394 orangdan sampel yang digunakan adalah sebanyak 80 sampel dengan sampling eror $10 \%$.. Uji satistik yang digunakan yaitu : uji validitas dan reliabilitas, uji korelasi , regresi linear sederhana, uji t dan uji F dimana signifikansi kepercayaan 95\% $(\alpha=0,05)$. Semua uji statistik dilakukan dengan menggunakan program SPSS (Statistical Package for Social Science) versi 19. Hasil penelitian menunjukkan Kepemimpinan, diklat dan budaya organisasi secara bersama-sama memiliki pengaruh positif terhadap kinerja pegawai yang ditunjukkan

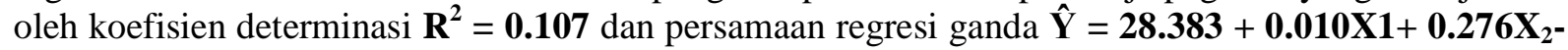
$\mathbf{0 . 0 0 2 X}_{3}$ sehingga kontribusi dan pengaruh kepemimpinan, diklat dan budaya organisasi secara bersama-sama terhadap kinerja pegawai adalah signifikan.
\end{abstract}

Keyword : kepemimpinan, diklat, budaya organisasi, kinerja pegawai 


\section{PENDAHULUAN}

Penilaian kinerja perlu mendapat perhatian yang serius pada instansi pemerintah.Menurut Sarundajang (2000), karyawan atau pegawai yang efektif adalah pegawai yang mempunyai visi, agenda dan berorientasi pada hasil. Dengan demikian perlu adanya perubahan pola pikir para pegawai atau karyawan dari reaktif menjadi proaktif (antisipatif), dan yang beorientasi masalah menjadi berorientasi kepada pemecahan masalah serta dapat mengembangkan tekanan dan ketakutan menjadi mengembangkan percaya diri dan partisipasi.

Kepemimpinan adalah kemampuan positif memengaruhi orang dan sistem untuk memberikan dampak yang berguna dan mencapai hasil-hasil yang diinginkan..Peran seorang pemimpin adalah memberikan dorongan kerja bagi individu untuk mempunyai pandangan yang selalu mengarah pada ussaha memberikan hasil yang baik.

Salah satu cara yang dapat dilakukan dalam upaya meningkatan kinerja pegawai adalah para pegawai harus mendapatkan program pendidikan dan pelatihan yang memadai untuk jabatannya sehingga pegawai terampil dalam melaksanakan pekerjaannya. Budaya organisasi merupakan norma-norma dan nilai- nilai yang mengarahkan perilaku anggota organisasi (Luthans, 2002).Setiap orang akan berperilaku sesuai dengan budaya yang berlaku agar diterima di lingkungannya. Kepribadian seseorang akan dibentuk pula oleh lingkungannya dan agar kepribadian tersebut mengarah kepada sikap dan perilaku yang positif tentunya harus didukung oleh suatu norma yang diakui tentang kebenarannya dan dipatuhi sebagai pedoman dalam bertindak.

Berdasarkan latar belakang masalah diatas, penulis merumuskan masalah pada Bagaimana Pengaruh Kepemimpinan, Diklat dan Budaya Organisasi secara individual dan secara simultan terhadap Kinerja Pegawai Direktorat Jenderal Pembinaan Penempatan Tenaga Kerja Kemenaketrans RI.

Kepemimpinan (Leadership) menurut Gaspersz (2007) adalah proses dimana seseorang atau sekelompok orang (tim) memainkan pengaruh atas orang (tim) lain, menginspirasikan, memotovasi dan mengarahkan aktivitas mereka untuk mencapai sasaran atau tujuan. Kepemimpinan adalah kemampuan positif memengaruhi orang dan sistem untuk memberikan dampak yang berguna dan mencapai hasil-hasil yang diinginkan.

Menurut Warner Bennis (2006) Kepemimpinan efektif adalah :Kepemimpinan yang bisa menggerakkan organisasi dari kondisi saat ini ke kondisi masa depan, membentuk visi-visi kesempatan potensial bagi organisasi, menanamkan komitmen terhadap perubahan kepada karyawan dan menanamkan budaya dan strategi baru dalam organisasi yang memobilisasi dan memfokuskan energi dan sumberdaya. Salah satu cara yang dapat dilakukan dalam upaya meningkatan kinerja pegawai adalah dengan melalui pengembangan pegawai yaitu dengan melakukan pendidikan dan pelatihan (Ambar T.S dan Rosidah, 2003: 175). Untuk mencapai kinerja yang diharapkan dalam suatu organisasi atau instansi, para pegawai harus mendapatkan program pendidikan dan pelatihan yang memadai untuk jabatannya sehingga pegawai terampil dalam melaksanakan pekerjaannya (Anwar, 2005:67).

Definis Diklat menurut SP. Siagian (2003: 175178) mengemukakan sebagai berikut : PendidIkan adalah keseluruhan proses, teknik dan metode belajar mengajar dalam rangka mengalaihkan sesuatu pengetahuan dari seseorang kepada orang lain sesuai standar yang telah ditetapkan sebelumnya. Latihan adalah suatu proses belajar mengajar dengan menggunakan metode dan teknik tertentu dengan maksud untuk meningkatkan keterampilan dan kemampuan kerja seorang atau sekelompok orang.

Budaya organisasional adalah sistem makna, nilai-nilai dan kepercayaan yang dianut bersama dalam suatu organisasi yang menjadi rujukan untuk bertindak dan membedakan organisasi satu dengan organisasi lain (Mas'ud, 2004). Budaya organisasi selanjutnya menjadi identitas atau karakter utama organisasi yang dipelihara dan dipertahankan (Mas'ud, 2004). Suatu budaya yang kuat merupakan perangkat yang sangat bermanfaat untuk mengarahkan perilaku, karena membantu karyawan untuk melakukan pekerjaan yang lebih baik sehingga setiap karyawan pada awal karirnya perlu memahami budaya dan bagaimana budaya tersebut terimplementasikan. 
Budaya merupakan norma-norma dan nilai- nilai yang mengarahkan perilaku anggota organisasi (Luthans, 2002).Setiap orang akan berperilaku sesuai dengan budaya yang berlaku agar diterima di lingkungannya. Kepribadian seseorang akan dibentuk pula oleh lingkungannya dan agar kepribadian tersebut mengarah kepada sikap dan perilaku yang positif tentunya harus didukung oleh suatu norma yang diakui tentang kebenarannya dan dipatuhi sebagai pedoman dalam bertindak.

Keberhasilan perusahaan dalam memperbaiki kinerja perusahaannya sangat tergantung pada kualitas SDM yang bersangkutan dalam berkarya atau bekerja sehingga perusahaan perlu memiliki karyawan yang berkemampuan tinggi.Kinerja adalah hasil atau tingkat keberhasilan seseorang secara keseluruhan selama periode tertentu didalam melaksanakan tugas dibandingkan dengan berbagai kemungkinan, seperti standar hasil kerja, target atau sasaran atau criteria yang telah ditentukan terlebih dahulu dan telah disepakati bersama. (Rivai dan Basri, 2005)

Menurut Robins (2004) kinerja sebagai fungsi interaksi antara kemampuan atau ability (A) motivasi atau motivation (M) dan kesempatan atau opportunity $(\mathrm{O})$, yaitu kinerja $=(\mathrm{A} \times \mathrm{M} \times$ $\mathrm{O})$. Artinya : kinerja merupakan fungsi dari kemampuan, motivasi dan kesempatan.

Penelitian pertama dilakukan Irham Ari Wibowo (2010) denganjudulPengaruh Motivasi Kerja, Kepemimpinan, Dan Budaya Organisasi Terhadap Kinerja Pegawai Negeri Sipil (Studi Kasus pada Pegawai Negeri Sipil di Kabupaten Klaten).Hasil perhitungan koefisien determinasi diperoleh Adjusted R2 diperoleh angka 0,839 yang berarti hanya $83,9 \%$ kinerja pegawai dipengaruhi oleh variabel motivasi, kepemimpinan dan budaya organisasi, sementara sisanya sebesar $16,1 \%$ dipengaruhi variabel lain di luar model penelitian ini.

Penelitian kedua dilakukan oleh I Wayan Ardiantadan I Wayan Gede Supartha (2011) dengan judul Pengaruh Diklat, Kepemimpinan Dan Penerapan Budaya Organisasi Terhadap Kinerja Karyawan. Diperoleh hasil bahwa diklat, kepemimpinan, dan penerapan budaya organisasi secara parsial dan simultan berpengaruh positif dan signifikan terhadap kinerja karyawan Hotel Bali Dwipa.
Berdasarkan analisis dari pemikiran di atas, penulis membuat hipotesis sebagai berikut :

1. Terdapat pengaruh yang signifikan antara Kepemimpinan dengan Kinerja Pegawai Direktorat Jenderal Pembinaan Penempatan Tenaga Kerja Kemenaketrans RI.

2. Terdapat pengaruh yang signifikan antara Diklat dengan Kinerja Pegawai Direktorat Jenderal Pembinaan Penempatan Tenaga Kerja Kemenaketrans RI.

3. Terdapat pengaruh yang signifikan antara Budaya Organisasi dengan Kinerja Pegawai Direktorat Jenderal Pembinaan Penempatan Tenaga Kerja Kemenaketrans RI.

4. Terdapat pengaruh yang signifikan antara Kepemimpinan, Diklat dan Budaya Organisasi terhadap Kinerja Pegawai Direktorat Jenderal Pembinaan Penempatan Tenaga Kerja Kemenaketrans RI.

\section{METODE}

Data yang dibutuhkan dalam penelitian ini adalah data primer dan data sekunder yang diperoleh dari narasumber. Pengumpulan data dilakukan dengan cara menyebar kuesioner.

Populasi dalam penelitian ini adalah Pegawai Direktorat Jenderal Pembinaan Penempatan Tenaga Kerja Kemenaketrans RI yang berjumlah 394 orang pegawai. Jumlah sampel dalam penelitian ini ditetapkan menggunakan rumus Slovin dengan sampling error $10 \%$. Dan diperoleh sampel sebanyak 80 orang pegawai

Tahapan analisis data adalah sebagai berikut :

1. Pemberian nilai (scoring)

2. Uji Validitas dan Reliabilitas

3. Uji Normalitas

4. Analisi Regresi Linear Sederhana.

5. Analisis Regresi Berganda.

6. Pengujian Hipotesis

a. Uji - t untuk Regresi Linear Sederhana dengan $\alpha=5 \%$.

1) Jika t-hitung > t-tabel maka Ho ditolak dan Ha diterima yang

2) Jika t-hitung <t-tabel maka Ho diterima dan Ha ditolak.

b. Uji F untuk Regresi Berganda dengan $\alpha=$ $5 \%$.

1) Jika F-hitung > F-tabel maka Ho ditolak dan Ha diterima

2) Jika F-hitung < F-tabel maka Ho diterima dan Ha ditolak 


\section{HASIL DAN PEMBAHASAN}

\section{Hasil Penelitian}

Hasil perhitungan analisis regresi linear sederhana sebagai berikut :

1. Pengaruh kepemimpinan $\left(\mathrm{X}_{1}\right)$ terhadap kinerja pegawai $(\mathrm{Y})$ menghasilkan persamaan regresi sederhana $\mathrm{Y}=40.089-0.029 \mathrm{X}_{1}$. Dimana nilai koefisien determinasi $\left(\mathrm{r}^{2}\right)$ sebesar 0.002

2. Pengaruh Diklat $\left(\mathrm{X}_{2}\right)$ terhadap Kinerja Pegawai (Y)menghasilkan persamaan regresi sederhana $\mathrm{Y}=28.723+0.275 \mathrm{X}_{2}$. Dimana nilai koefisien determinasi $\left(\mathrm{r}^{2}\right)$ sebesar 0.375 .

3. Pengaruh Budaya Organisasi $\left(\mathrm{X}_{3}\right)$ terhadap kinerja pegawai $(\mathrm{Y})$ menghasilkan persamaan regresi sederhana $\mathrm{Y}=39.302-0.008 \mathrm{X}_{3}$. Dimana nilai koefisien determinasi $\left(\mathrm{r}^{2}\right)$ sebesar 0.010 .
Analisis Regresi Berganda digunakan untuk menganalisis pengaruh variabel independen Kepemimpinan $\left(\mathrm{X}_{1}\right)$, Diklat $\left(\mathrm{X}_{2}\right)$ dan Budaya Organisasi $\left(\mathrm{X}_{3}\right)$ secara bersama-sama atau simultan terhadap variabel dependen Kinerja Pegawai (Y). Hasil perhitungan analisis regresi berganda kepemimpinan $\left(\mathrm{X}_{1}\right)$, diklat $\left(\mathrm{X}_{2}\right)$ dan budaya organisasi $\left(\mathrm{X}_{3}\right)$ terhadap kinerja pegawai (Y) menghasilkan persamaan regresi ganda $\mathrm{Y}=28.383+0.010 \mathrm{X} 1+0.276 \mathrm{X}_{2}$ $0.002 \mathrm{X}_{3}$. Dimana nilai koefisien determinasi $\left(\mathrm{r}^{2}\right)$ sebesar 0.107, seperti terlihat pada gambar berikut:

Coefficients $^{\mathrm{a}}$

\begin{tabular}{|c|c|c|c|c|c|c|}
\hline \multirow[b]{2}{*}{ Mode } & & \multicolumn{2}{|c|}{$\begin{array}{l}\text { Uns tandardized } \\
\text { Coefficients }\end{array}$} & \multirow{2}{*}{$\begin{array}{c}\text { Standardized } \\
\text { Coefficients }\end{array}$} & \multirow[b]{2}{*}{$\mathrm{t}$} & \multirow[b]{2}{*}{ Sig. } \\
\hline & & $\mathrm{B}$ & Std. Error & & & \\
\hline \multirow[t]{4}{*}{1} & (Constant) & 28.373 & 4.655 & & 6.096 & .000 \\
\hline & Kepemimpinan (X1) & .010 & .099 & .014 & .101 & .920 \\
\hline & Diklat (X2) & .276 & .079 & .377 & 3.504 & .001 \\
\hline & Budaya Organis asi (X3) & -.002 & .111 & -.003 & -.019 & .985 \\
\hline
\end{tabular}

a. Dependent Variable: Kinerja Pegaw ai (X4)

\section{Pengujian Hipotesis}

a. Uji - t untuk Regresi Linear Sederhana dengan $\alpha=5 \%$.

Hasil perhitungan uji $\mathrm{t}$ diperoleh nilai-nilai $t_{\text {hitung }}$ sebagai berikut :

1. Pengaruh kepemimpinan $\left(\mathrm{X}_{1}\right)$ terhadap kinerja pegawai $(\mathrm{Y})$ menghasilkan $\mathbf{t}_{\text {hitung }}=$ $\mathbf{- 0 . 3 5 8}$ pada level signifikansi Sig. $=0.721$

2. Pengaruh Diklat $\left(X_{2}\right)$ terhadap Kinerja Pegawai $(\mathrm{Y})$ menghasilkan $\mathbf{t}_{\text {hitung }}=\mathbf{3 . 5 7 4}$ pada level signifikansi Sig. $=0,001$
3. Pengaruh budaya organisasi $\left(X_{3}\right)$ terhadap kinerja pegawai $(\mathrm{Y})$ menghasilkan $\mathbf{t}_{\text {hitung }}=$ $\mathbf{- 0 . 0 8 6}$ pada level signifikansi Sig. $=0.931$

b. Uji F untuk Regresi Berganda dengan $\alpha=$ $5 \%$.

Hasil perhitungan uji $\mathrm{F}$ diperoleh nilai $\mathrm{F}_{\text {hitung }}=$ 0.009 yang dicapai pada level signifikansi 0.009 , seperti pada gambarberikut:

ANOV A

\begin{tabular}{|c|c|c|c|c|c|c|}
\hline Model & & $\begin{array}{c}\text { Sum of } \\
\text { Squares }\end{array}$ & $\mathrm{df}$ & Mean Square & $\mathrm{F}$ & Sig. \\
\hline \multirow[t]{3}{*}{1} & Regression & 136.761 & 3 & 45.587 & 4.153 & $.009^{a}$ \\
\hline & Residual & 834.226 & 76 & 10.977 & & \\
\hline & Total & 970.988 & 79 & & & \\
\hline
\end{tabular}

a. Predic tors: (Cons tant), Buday a Organisasi (X3), Diklat (X2), Kepemimpinan (X1)

b. Dependent Variable: Kinerja Pegaw ai (X4) 


\section{Pembahasan Hasil}

\section{Pengaruh Individual Kepemimpinan terhadap Kinerja Pegawai}

Pengaruh individual kepemimpinanterhadap kinerja pegawai ditunjukan oleh koefisien determinasi $\mathrm{r}^{2}=0.002$ dan persamaan regresi sederhana $\hat{\mathrm{Y}}=40.089-0.029 \mathrm{X}_{1} .$. Koefisien determinasi $\left(\mathrm{r}^{2}\right)=0.002$ memiliki arti bahwa kepemimpinan secara individual memiliki kontribusi sebesar $0.2 \%$ bagi terbentuknya kinerja pegawai sedangkan $99.8 \%$ sisanya terjadi karena kontribusi variabel selain kepemimpinan. Persamaan regresi sederhana $\hat{Y}=40.089$ $0.029 \mathrm{X}_{1}$, menunjukan bahwa kepemimpinan tidak memiliki pengaruh positif terhadap kinerja pegawai dimana setiap kenaikan satu satuan pada variabel kepemimpinan akan menurunkan kinerja pegawai sebesar 0.029 satuan.

Hasil uji hipotesis dimana nilai $t_{\text {hitung }}<t_{\text {tabel }}(-$ $0,358<1,671)$ menunjukkan bahwa hipotesis pertama tidak terbukti dimana kepemimpinan tidak memiliki pengaruh positif terhadap kinerja pegawai sehingga peningkatan kepemimpinan tidak akan meningkatkan kinerja pegawai.

\section{Pengaruh Individual Diklat terhadap Kinerja Pegawai}

Pengaruh individual diklat terhadap kinerja pegawai ditunjukkan oleh koefisien determinas $\mathrm{r}^{2}$ $=\mathbf{0 . 3 7 5}$ dan persamaan regresi sederhana $\hat{Y}=$ $\mathbf{2 8 . 7 2 3}+\mathbf{0 . 2 7 5} \mathrm{X}_{2}$. Koefisien determinasi $\left(\mathbf{r}^{2}\right)=$ 0.375 memiliki arti bahwa diklat secara individual memiliki kontribusi sebesar $\mathbf{3 7 , 5 \%}$ bagi terbentuknya kinerja pegawai sedangkan $\mathbf{6 2 , 5 \%}$ sisanya terjadi karena kontribusi variabel selain diklat.

Persamaan regresi sederhana $\hat{\mathbf{Y}} \mathbf{= 2 8 . 7 2 3}+$ $\mathbf{0 . 2 7 5 X}_{2}$. menunjukkan bahwa diklat memiliki pengaruh positif terhadap kinerja pegawai dimana setiap kenaikan satu satuan pada variabel diklat akan meningkatkan kinerja pegawai sebesar $\mathbf{0 . 2 7 5}$ satuan.

Hasil uji hipotesis dimana nilai $t_{\text {hitung }}>t_{\text {tabel }}(3,574$ $>1,671)$ menunjukkan bahwa hipotesis pertama terbukti dimana diklat memiliki pengaruh positif terhadap kinerja pegawai sehingga peningkatan diklatakan meningkatkan kinerja pegawai.

\section{Pengaruh Individual Budaya Organisasi terhadap Kinerja Pegawai \\ Pengaruh individual budaya organisasi terhadap kinerja pegawai ditunjukkan oleh koefisien determinasi $\mathbf{r}^{\mathbf{2}}=\mathbf{0 . 0 1 0}$ dan persamaan regresi sederhana $\hat{\mathbf{Y}}=39.302-\mathbf{0 . 0 0 8}_{\mathbf{3}}$. Koefisien}

determinasi $\left(\mathbf{r}^{2}\right)=\mathbf{0 . 0 1 0}$ memiliki arti bahwa budaya organisasi secara individual memiliki kontribusi sebesar $\mathbf{1 , 0 \%}$ bagi terbentuknya kinerja pegawai sedangkan $\mathbf{9 8 . 9 \%}$ sisanya terjadi karena kontribusi variabel selain budaya organisasi.

Persamaan regresi sederhana $\hat{Y}=39.302$ $0.008 \mathrm{X}_{3}$. menunjukkan bahwa budaya organisasitidakmemiliki pengaruh positif terhadap kinerja pegawai dimana setiap kenaikan satu satuan pada variabel budaya organisasi akan menurunkankinerja pegawai sebesar 0.008 satuan.

Hasiluji hipotesis dimana nilai $\mathrm{t}_{\text {hitung }}<\mathrm{t}_{\text {tabel }}$ ($0,086<1,671)$ menunjukkan bahwa hipotesis pertama tidakterbukti dimana budaya organisasitidakmemiliki pengaruh positif terhadap kinerja pegawai sehingga peningkatan budaya organisasitidakakan meningkatkan kinerja pegawai.

Pengaruh Simultan Kepemimpinan, Diklat dan Budaya Organisasi terhadap Kinerja Pegawai

Pengaruh simultan kepemimpinan, diklat dan budaya organisasi terhadap kinerja pegawai ditunjukkan oleh koefisien determinasi $\mathbf{R}^{2}=$ 0.107 dan persamaan regresi ganda $\hat{\mathbf{Y}}=\mathbf{2 8 . 3 8 3}+$ $0.010 X 1+0.276 X_{2}-0.002 X_{3}$.

Koefisien determinasi $\left(\mathrm{R}^{2}\right)=0.107$ memiliki arti bahwa kepemimpinan, diklat dan budaya organisasi secara bersama-sama memiliki kontribusi sebesar $\mathbf{1 0 . 7 \%}$ bagi terbentuknya kinerja pegawai sedangkan $89.3 \%$ sisanya terjadi karena kontribusi variabel selain kepemimpinan, diklat dan budaya organisasi.

Persamaan regresi ganda $\hat{\mathbf{Y}}=\mathbf{2 8 . 3 8 3}+\mathbf{0 . 0 1 0 X 1 +}$

$\mathbf{0 . 2 7 6 X}_{\mathbf{2}}-\mathbf{0 . 0 0 2}_{\mathbf{3}}$ menunjukkan bahwa kepemimpinan memiliki pengaruh positif terhadap kinerja pegawai dimana setiap kenaikan satu satuan pada variabel kepemimpinan akan meningkatkan kinerja pegawai sebesar 0.010 satuan dengan asumsi variabel lain konstan dan variabel diklat dan budaya organisasi berlaku sebagai kontrol.

Diklat memiliki pengaruh positif terhadap kinerja pegawai dimana setiap kenaikan satu satuan pada variabel diklat akan meningkatkan kinerja pegawai sebesar 0.276 satuan dengan asumsi variabel lain konstan dan variabel kepemimpinan berlaku sebagai kontrol.

Budaya organisasi memiliki pengaruh negatif terhadap kinerja pegawai dimana setiap kenaikan satu satuan pada variabel budaya organisasi akan menurunkan kinerja pegawai sebesar 0.002 
satuan dengan asumsi variabel lain konstan dan variabel kepemimpinan dan diklat berlaku sebagai kontrol.

Hasil uji hipotesis dimana nilai $\mathrm{F}_{\text {hitung }}<\mathrm{F}_{\text {tabel }}$ $(0.009<8,57)$ menunjukkan bahwa hipotesis pertama tidak terbukti dimana kepemimpinan, diklat dan budaya organisasi secara simultan/bersama-sama tidak memiliki pengaruh terhadap kinerja pegawai..

\section{Implikasi Manajerial}

Kontribusi individual dan simultan kepemimpinan, diklat dan budaya organisasi terhadap kinerja pegawai termasuk dalam kategori sangat rendahyaitu antara $0 \%$ sampai dengan $19.9 \%$, artinya model persamaan regresi yang terbentuk kurang fit untuk memprediksi kinerja pegawai dengan variabel masukan kepemimpinan, diklat dan budaya organisasi. Hasil penelitian juga menunjukkan bahwa secara individual variabel kepemimpinan dan budaya organisasi tidak terbukti memiliki pengaruh yang signifikan terhadap kinerja pegawai, sedangkan variable diklat secara individual terbukti memiliki pengaruh positif terhadap kinerja pegawai. Oleh karena itu upaya peningkatan kinerja pegawai harus senantiasa dilakukan demi tercapainya tujuan organisasi. Oleh karena itu organisasi dapat melaksanakan kegiatannya dengan menekankan upaya pada peningkatan dengan variable lain selain kepemimpinan dan budaya organisasi. Tetapi secara bersama-sama upaya peningkatan kepemimpinan, diklat dan budaya organisasi harus tetap dilaksanakan secara berkesinambungan. Hal ini perlu dilakukan mengingat kontribusi kepemimpinan, diklat dan budaya organisasi secara bersamasama jauh lebih besar dari pada kontribusinya secara individual.

\section{SIMPULAN DAN SARAN}

\section{Simpulan}

1. Kepemimpinan secara individual tidak memiliki pengaruh positif terhadap kinerja pegawai yang ditunjukkan oleh koefisien determinasi $\mathbf{r}^{2}=\mathbf{0 . 0 0 2}$ dan persamaan regresi sederhana $\hat{\mathbf{Y}}=40.089+(-0.029) \mathrm{X}_{1}$, yang signifikan pada taraf uji penelitian yaitu $\alpha=$ 0,05 sehingga kontribusi dan pengaruh kepemimpinan terhadap kinerja pegawai adalah tidak signifikan. Hasil tersebut memiliki arti bahwa $\mathbf{0 . 2 \%}$ variasi kinerja pegawai dipengaruhi secara individual oleh kepemimpinan dimana setiap kenaikan satu satuan kepemimpinan akan menurunkan kinerja pegawai sebesar $\mathbf{0 . 0 2 9}$ satuan.

2. Diklat secara individual memiliki pengaruh positif terhadap kinerja pegawai yang ditunjukkan oleh koefisien determinasi $\mathbf{r}^{2}=$ $\mathbf{0 . 1 4 1}$ dan persamaan regresi sederhana $\hat{\mathbf{Y}}=$ $\mathbf{2 8 . 7 2 3}+\mathbf{0 . 2 7 5} \mathrm{X}_{\mathbf{2}}$ yang signifikan pada taraf uji penelitian yaitu $\alpha=0,05$ sehingga kontribusi dan pengaruh diklat terhadap kinerja pegawai adalah signifikan. Hasil tersebut memiliki arti bahwa $\mathbf{1 4 . 1 \%}$ variasi kinerja pegawai dipengaruhi secara individual oleh diklat dimana setiap kenaikan satu satuan diklat akan meningkatkan kinerja pegawai sebesar 0.275 satuan.

3. Budaya organisasi secara individual tidak memiliki pengaruh positif terhadap kinerja pegawai yang ditunjukkan oleh koefisien determinasi $\mathbf{r}^{2}=\mathbf{0 . 0 0 0}$ dan persamaan regresi

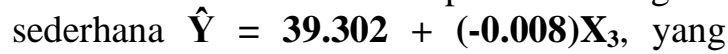
signifikan pada taraf uji penelitian yaitu $\alpha=$ 0,05 sehingga kontribusi dan pengaruh budaya organisasi terhadap kinerja pegawai adalah tidak signifikan. Hasil tersebut memiliki arti bahwa $\mathbf{0 \%}$ variasi kinerja pegawai dipengaruhi secara individual oleh budaya organisasi dimana setiap kenaikan satu satuan budaya organisasi akan menurunkan kinerja pegawai sebesar 0.008 satuan.

4. Kepemimpinan, diklat dan budaya organisasi secara bersama-sama memiliki pengaruh positif terhadap kinerja pegawai yang ditunjukkan oleh koefisien determinasi $\mathbf{R}^{2}=$ $\mathbf{0 . 1 0 7}$ dan persamaan regresi ganda $\hat{\mathbf{Y}}=$ $28.383+0.010 \mathrm{X} 1+0.276 \mathrm{X}_{2}+(-0.002) \mathrm{X}_{3}$ yang signifikan pada taraf uji penelitian yaitu $\alpha=0,05$ sehingga kontribusi dan pengaruh kepemimpinan, diklat dan budaya organisasi secara bersama-sama terhadap kinerja pegawai adalah signifikan. Hasil tersebut memiliki arti bahwa $\mathbf{1 0 . 7 \%}$ variasi kinerja pegawai dipengaruhi secara bersama-sama oleh kepemimpinan, diklat dan budaya organisasi dimana setiap kenaikan satu satuan kepemimpinan akan meningkatkan kinerja pegawai sebesar $\mathbf{0 . 0 1 0}$ satuan dan setiap kenaikan satu satuan diklat akan meningkatkan kinerja pegawai sebesar $\mathbf{0 . 2 7 6}$ satuan, serta setiap kenaikan satu satuan budaya organisasi akan menurunkan kinerja pegawai sebesar $\mathbf{0 . 0 0 2}$ satuan. 


\section{Saran}

1. Upaya peningkatan kinerja pegawai harus senantiasa dilakukan demi tercapainya tujuan organisasi. Dalam penelitian ini terbukti bahwa kepemimpinan, diklat dan budaya organisasi baik individual maupun simultan memiliki pengaruh positif terhadap kinerja pegawai sehingga untuk meningkatkan kinerja pegawai, organisasi dapat melaksanakannya dengan menekankan upaya pada peningkatan kepemimpinan, diklat dan budaya organisasi didalam institusi.

2. Upaya peningkatan kepemimpinan, diklat dan budaya organisasi harus dilaksanakan secara bersamaan dan berkesinambungan. Hal ini perlu dilakukan mengingat kontribusi kepemimpinan, diklat dan budaya organisasi secara bersama-sama jauh lebih besar dari pada kontribusinya secara individual.

3. Perlu dilakukan penelitian lanjutan secara lebih mendalam untuk mendapatkan generalisasi hasil penelitian khususnya mengenai pengaruh kepemimpinan, diklat dan budaya organisasi terhadap kinerja pegawai.

\section{DAFTAR RUJUKAN}

Anwar Prabu Mangkunegara. 2004. Manajemen Sumber Daya Manusia. Perusahaan cetakan pertama. Jakarta: PT. Remaja Rsodakarya.

Ardianta, I Wayandan Gede, I Wayan Supartha. Pengaruh Diklat, Kepemimpinan Dan Penerapan Budaya Organisasi Terhadap Kinerja Karyawan. E-Jurnal Manajemen Universitas Udayana, Vol 3, No 9 (2014)

Basri, A. F. M., \&Rivai, V. 2005. Performance appraisal. Jakarta: PT Raja. Grafindo Persada.

Bennis, Warren and Nanus, Burt. 2006. "Leaders Strategi untuk Mengemban Tanggung Jawab", Jakarta: PT. Bhuana Ilmu Populer.

Fuad, Mas'ud. 2004. Survai Diagnosis Organisasional (Konsepdan Aplikasi).
Semarang:Badan Penerbit Universitas Diponegoro.

Gaspersz, Vincent. 2007. "Organizational Excellence - Model Strategik Menuju World Class Quality Company". Jakarta: PT. Gramedia.

Luthans E.A., 2002. Organizational Behavior, Sixth Edition, Singapore: McGraw Hill Book Co.

Robbins, Stephen P., 2004. Organizational Behaviour six edt, NewJersey, Prentice Hall International Inc.

Sarundajang. 2000. Pemerintahan Daerah di Berbagai Negara. Jakarta: Pustaka. Sinar Harapan.

Siagian, Sondang P., Manajemen Sumber Daya Manusia, Jakarta, Bumi Aksara, 2003.

Sulistiyani, Ambar dan Rosyidah. 2003. ManajemenSumberdayaManusia, Yogyakarta: Penerbit Graha Ilmu.

Wibowo, Irham Ari. Pengaruh Motivasi Kerja, Kepemimpinan, Dan Budaya Organisasi Terhadap Kinerja Pegawai Negeri Sipil (Studi Kasus pada Pegawai Negeri Sipil di Kabupaten Klaten).Universitas Muhammadiyah Surakarta. 2013 